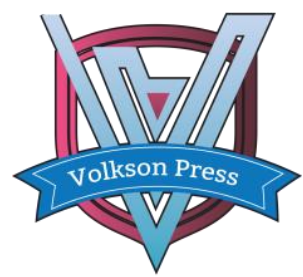

Contents List available at VOLKSON PRESS

\title{
E-Commerce Marketing Model and Comparison of High Quality Agricultural Products in County Region: Based on the Case of Qingyang County Native Eggs
}

\author{
Xuye Liu 1,a \\ ${ }^{1}$ School of Management Wuhan Donghu University Wuhan City Hubei Province P.R.China. \\ aEmail:150119680@qq.com
}

This is an open access article distributed under the Creative Commons Attribution License, which permits unrestricted use, distribution, and reproduction in any medium, provided the original work is properly cited.

\section{ARTICLE DETAILS}

\section{Article History:}

Received 02 october 2017

Accepted 06 october 2017

Available online 11 october 2017

Keywords:

County region agriculture, High quality agricultural products, Ecommerce, Marketing model.

\section{ABSTRACT}

The concept of county region had put forward on the Party's 16th National Congress of China in the first time. Agriculture is the foundation of the county region economy. The e-commerce of agricultural products has important role to promote agricultural modernization. And e-commerce marketing is the key factor to promote the development of electronic commerce. This paper takes native egg as an example study e-commerce marketing model and comparison of high quality agricultural products in county region. To describes the status of production and salefor Qingyang native egg this paper analyzes e-commerce marketing models and their advantages and disadvantages. Finally, according to the analysis conclusion some suggestions are put forward for aquaculture enterprises and farmers to choose marketing models.

\section{Introduction}

The concept of county region, which mainly based on the special national conditions in China, was put forward in the first time on the Party's 16th National Congress. The administrative divisions at the county level are taken as geographic space in China. The county regional boundaries is clear and has certain independence and motility. The particularity of county lies in the fact coupling with city and towns and rural areas. Hence, there is special function of county for administrative and economic divisions in China. Agriculture is the foundation of the county region economy in China. New opinion was raised on the Fifth Plenary Session of the Party's 18th developing characteristics county region economy in Thirteen Five Planning. The decision of govement will vigorously promotes agricultural modernization. It plays a very important role that e-commerce of county agricultural products promotes agricultural modernization. Many Problems can be solved by e-commerce of county agricultural, for instance agricultural products selling, information asymmetry, circulation link. It is one of the most important ways to improve the county agricultural products circulation efficiency, and flourish the county region economy (Wang qian, $2016)^{[1]}$. So far, the literature on the county region agricultural e-commerce are relatively few, and they mainly have discussed from the following three aspects. Firstly, it has advantages and necessity to establish e-commerce platform of agricultural products based on the county region. (Ming zeng, 2014) [2]. Secondly, because of weak of the farmers for agricultural products e-commerce, network businessman has been difficult to meet the development of agricultural e-commerce. The farmers capacity of innovation is a key to develop the county agricultural e-commerce (Wang qian, 2016) ${ }^{[1]}$. Thirdly, it is important for development of the county region agricultural electronic commerce. (Li Ying, 2015; Zhang Jun, Zhang Jingzhong, 2015; Lin Weigong, Xu Zhenggong etc., 2015; Chen Hong, 2016; Chen Liangng, 2017) [3]-[7]. Different from the above literature, this paper hopes to provide beneficial supplement for the study of the county region agricultural e-commerce by exploring county high quality agricultural products e-commerce marketing model.

\section{Production and sale}

\subsection{Good natural breeding conditions}

There is unique regional characteristic to county region agricultural products. Which products can be produced and its quality depends on the county resources endowment. Qingyang county belongs to Chizhou city in Anhui province. It located in the north in the south of Anhui, the middle and lower of the Yangtze River (north latitude $30^{\circ} 19^{\prime} 16^{\prime \prime} \sim 30^{\circ} 50^{\prime} 44^{\prime \prime}$ ). Qingyang county is $40 \mathrm{~km}$ wide from east to west, 65 kilometers long from north to south, a total area of 1180.6 square kilometers. The terrain is south high and north low. There is valley basin on Qingtong river and its tributaries and in the middle and lower reaches of Qixing river. Many low mountains and hills are in the county. The forest coverage rate is over $57 \%$. Qingyang is well known by "seven hills, one water, one field, one road and farm village". Qingyang county is humid subtropical monsoon climate zone, hot summer and cold winter. The spring and autumn is mild. Rainfall is abundant. Sunshine hours is long, and frost-free period is short, plum rain period is about 40 days. The geographical position is superior, climate conditions is comfortable, environment is beautiful because of many low hills, so Qingyang has very good natural conditions for breeding native chicken. Eating grain and worm and drinking mountain spring water in the natural ecological environment, the native chicken is succulent and delicate. Compared with the ordinary eggs, the native egg in Qingyang county not only riboflavin content is high, but also taste is better. County native chicken and eggs gained national pollution-free and green food certification. Because the native eggs have been reported by CCTV7, the native eggs are loved by consumers especially comsmers in large and medium-sized cities.

\subsection{Breeding model of industrialization}

Since this century, the native chicken breeding model in Qingyang county is gradually to the industrialization of cage-free from family cage-free. The native chicken is cultivated as agricultural leading industry by the government. Because of industrialization management, standardization breeding, the brand development, the native chicken industrialization has been achieved positive results. By 2015, the amount of native chicken breeding in the county is 10 million. The gross output value is more than 100 million yuan. The annual output of native eggs is 2100 tons, and the gross output value is more than 30 million. The per capita income growth of farmers is more than 500 yuan. In the county the native chicken association in the south of Anhui includes 23 group members and 137 individual members, and the total assets is 65 million yuan. It drives more than 3500 peasant households. The farmers with breeding more than ten thousand native chicken are more than 46 households, and more than 5000 about 68 households. The mass breeding rate is more than $40 \%$ (1). Qingyang county government guide to establish the native chicken association in the south of Anhui. The government of county support breeding farmer from policy and technology. At the same time, the government formulates plans for the development of industry to promote 
the breeding pattern of the native chicken by companies + rural cooperatives + large farming. As early as 2004 , the native chicken base in Qingyang county had approved the fifth group of national agricultural standardization demonstration area by the national standardization management committee. Relying on the model of companies + rural cooperatives + large farming, scale management and industrialization are realized, and market competitiveness can be enhanced.

\subsection{Sale way of combination to traditional and modern}

The sale way of Qingyang native eggs combines tradition and modern. It manifests three ways. The first sale way is traditional small-scale farmers producing and selling. This is a convenient and safe way, but the sale quantity is few, sale quantity accounts for about $15 \%$ of the total in Qingyang county. The second is online sale through company + association(cooperative) + large farming. Some farmers cooperatives set up a website by themselves. They find eggs acquisition merchants through the web site. The sale way gets rapid development, and the salequantity accounts for about $25 \%$ of the total. And the third is the network retail sales. And breeding enterprises or farmers face with consumers directly. They can have their own brand and pricing, and negotiate with consumers. This sale way is flexible and lower cost. The sale quantity accounts for about $60 \%$ of the total.

\section{E-commerce marketing models}

Since 2010 years, the development of e-commerce has been getting more and more quickly in Qingyang county. The county government introduced the provisions about speed up the development of e-commerce. By 2015 characteristic agricultural products electronic retailing shops had grown to more than 400 .

\subsection{C2C model}

C2C model is electronic commerce of customer to customer and individual to individual. During the rapid development of e-commerce, C2C model of native eggs gets fast development in Qingyang. With the help of a third party platform to open network stores, every farmer can independent trade the native eggs. By 2015 it had set up 335 network stores to salenative eggs on the Taobao and Jingdong, and 312 shops were in Taobao. The network shop with demonstration effect is a family agricultural specialties in Jiuhua Mountain. With good ecological breeding environment, fine native varieties, pristine mountain green, high-quality product quality, the network shop got the national geographic protection products. There are 23 online shops in Jingdong, one of them is the Jibenshang proprietary brand shop in Chinese specialty. Its native eggs are very popular.

\subsection{B2B model}

B2B model refers to the commercial transactions between business and business. Because of large size transaction, some larger native eggs production enterprises and cooperatives provide some agent products in addition to online retail. By 2015 there were 98 dealerships selling county native eggs on Taobao and Jingdong. Farming scale gets larger, there are quite a few enterprises signed contract agents, such as Jiuhua Zhou Poultry Industry with industry experience for 23 years. The enterprise integrates breeding baby native chick, hatching eggs and selling native eggs. The enterprise established a long-term and stable relations between many agents by signed a contract, in addition to direct manufacturers on Alibaba. Providing preferential price and logistics transportation measure for the agents, they get a price discount and logistics facilities. It achieves win-win cooperation manufacturers and agents.

\subsection{C2B model}

Because food is related to nutrition and health of consumers, consumers pay more attention to food safety and quality. They are willing to directly orders with the farming business or farmers. So, the model that they choose kinds of baby chick and ways of breed according to the customer request is launched by many enterprises and farmers. This model meet the personalized demand. In 2012, few enterprises and farmers did it. While more than 30 carried out this model of production and sale in 2015. And there is another C2B model for Qingyang native eggs. Due to native eggs are fragile and short freshness time, the seller should fully consider the logistics security and freshness time. They exquisite package the native eggs before selling. When some breeding enterprise or farmers have a lot of orders, packing is a lot of work. They have to outsource food packaging company to design a protective or gift box packaging. This C2B model is popular in Qingyang county.

\subsection{0 model}

020 model is a combination of online and offline. Qingyang native chicken breeding farmers professional co-operatives and several agricultural enterprises unite together to .build the online platform. They not only provide native eggs and chicken, what is more important, but also provide online consulting and advertising. Consumers can order online and pick up the goods offline. This kind of 020 e-commerce marketing model develops better for native eggs in Qingyang county. Jiuhua Mountain is a national $5 \mathrm{~A}$ level scenic area that many tourists visit every year. Jiuhua Mountain scenic area tickets of rural tourism experience can be sold on the Meituan website. Tourists can choose and book in early online. Then tourists can experience the melon and fruit picking, picking up the egg of farmhouse and other rural life. The model,which is displaying, promoting online, experiencing and buying offline, is very fast growth. The growth of sale speed was at the rate of $22 \%$ from 2012 to 2015 .

\section{Advantages and disadvantages of native eggs marketing models}

Qingyang County native egg marketing model includes C2C, B2B, B2C and O20.And these marketing models have advantages and disadvantages.

\subsection{C2C native egg marketing model}

C2C marketing model salenative eggs by third-party platform of Taobao and Jingdong. The model has many advantages. Firstly, the sellers have a huge of buyers on same platform, the market are greater, the potential consumers are more. Secondly, the salespeed is fast. Qingyang county native eggs in online salequantity accounted for $80 \%$ of the total. In 2015 the number of the $\mathrm{C} 2 \mathrm{C}$ model was more than $60 \%$ of the total online saleand the sum of other online salemodel. Thirdly, the salerange is wide. Market of traditional salemodel is small and little fame. Qingyang native egg C2C model expanding saleto the provincial, national and overseas.

C2C marketing model Qingyang county native eggs also has some disadvantages. Firstly, logistics problem. Salequantity is small for single order of $\mathrm{C} 2 \mathrm{C}$ marketing model, eggs is easy broken in the logistics process, and freshness time is short. So the cost of packing and logistics is higher. Secondly, the after-saleservice. Consumers pay attention to not only the price, but also the quality of the goods itself. Customers are not satisfied with the product or the eggs damaged during the process of logistics need to return, businesses are easy to get serious losses.

\subsection{B2B native egg marketing model}

The popularity of Qingyang county native eggs is increasing. More and more companies (or business) are willing to become a saleagent. B2B model has significant advantage. Firstly, the amount of single transaction is larger. This reduce logistics costs and loss during the process of logistics. Secondly, there are stable business relations with many agents by signing a contract. Thirdly, the B2B model can reduce human input and save more manpower cost compare to the $\mathrm{C} 2 \mathrm{C}$ and $\mathrm{B} 2 \mathrm{~B}$ model.

B2B marketing model has obvious disadvantages for Qingyang county native eggs. Firstly, the selling price is lower than C2C model. It's harmful to profits of enterprises and farmers. Secondly, the product to be easily pretended. Because Qingyang county native eggs have a good brand awareness, some of agents pretend Qingyang native eggs with the other brand eggs, even ordinary eggs.

\subsection{C2B native egg marketing model}

C2B native egg marketing model of Qingyang county native eggs has the following advantages. The first one is the consumer can choose a variety of chicken and chicken feeding. The eggs of this model can timely be saled, and captal circulation is fast. Second, eggs prices of the model significantly higher than the market price, and profit is higher. Final, the eggs is fresh because of short sale time.

C2B model has significant disadvantages. Firstly, different consumers have different request for varieties and feed of chicken, it is difficult to feed for companies and farmers. Second, the cost increased significantly. It is necessary to increase investment of capital and technology. Final, part of the consumer break contract and lead to loss of farmers and enterprises.

\subsection{O20 native egg marketing model}

O20 marketing model of Qingyang county native eggs has the following advantages. Firstly, the marketing model books an order online at any time. And it break the time limit to purchase. Secondly, consumers can offline purchase at any time. They can choose satisfactory products. Thirdly, 
consumers can book orders online and buy products off-line. Combineing online and offline can meet different consumer demand.

The disadvantages are few. Firstly, because of picking up the goods offline, the distance is the biggest restrict factor to this pattern. So this model can be got only in surrounding areas not far away from Qingyang county. Secondly, consumers pick up the goods or visit to origin production enterprises.

\section{Conclusion and recommendations}

According to the analysis above the following conclusions can be obtained. Firstly, native eggs saleproportion of $\mathrm{C} 2 \mathrm{C}, \mathrm{B} 2 \mathrm{~B}, \mathrm{~B} 2 \mathrm{C}$, and $02 \mathrm{O}$ marketing models in Qingyang County has over 80\%, sale market cover national and Asia. Secondly , C2C model salequantity has over online $60 \%$ of total sale quantity, this model becomes the biggest online sale model of native eggs in Qingyang County. Thirdly,the 020 marketing model has the fastest growth, and it powerfully promotes native eggs e-commerce marketing growth in Qingyang County. At last,the C2B marketing model is the best way to meet the needs of consumer individual demand,and it is in line with future trends in consumption.How Farming enterprise and farmers choose species network marketing models? The following recommendations can be put forward.At first, the farming enterprise or farming farmers should consider their resources situation, including funds, technology, human, farming scale and market of understand. At second, market positioning of products is very important, including products the low- end products or high-end products, outside market or domestic market. At last, thier development planning should be forward-looking, including mainly production sale or consumer experiences or a combination of the two and so on

\section{Comments}

(1) Source: Statistical Yearbook of the Anhui Province, 2015.

(2) Government of qingyang County open network: http:http://xxgk.ahqy.gov.cn/

\section{Acknowledgements}

This work was supported by the grants from Hubei Provincial Collaborative Innovation Centre of Agricultural E-Commerce (under Construction ) (Wuhan Donghu university research [2015] No. 11 Document). Thone number:+86-013554521522

\section{References:}

[1] Qian Wang. County agricultural e-commerce innovation [D]. Shijiazhuang: Hebei economic and trade University in 2016 (3): 1-3.

[2] Zeng Ming. Construction of County Agricultural Products E-commerce Platform and Applications [J]. Business Beview, 201407:1-3.

[3] Li Ying. County Agricultural E-commerce Development Strategy-a Typical Study of Dali in Jianchuan County [J]. Agricultural Sciences, 2015. (06): 16:56.

[4] Chen Hong. Counties in Hebei Province Agricultural Development Countermeasures in the Study of Electronic Commerce [J]. Hebei Enterprises, 2016 (12): 129-130.

[5] Zhang Jun, Zhang Jingzhong. Agricultural Development Strategy of Ecommerce in the County Shanxi Province [J]. Journal of Agriculture, 2015 (12): 124-127.

[6] Lin Weihong, Xu Zhenghong, Shen Xiao Fei. County Agricultural Ecommerce Development Strategy [J]. Zhejiang Agricultural Sciences, 2015 (01): 127-130.

[7] Chen Liangang. Network Services Driver's County Agriculture Development Model of E-commerce in Hubei Province [J]. National Circulation, 2017 (04): 16-17. 